\title{
QUALITY ASSURANCE IN MEDICAL CARE
}

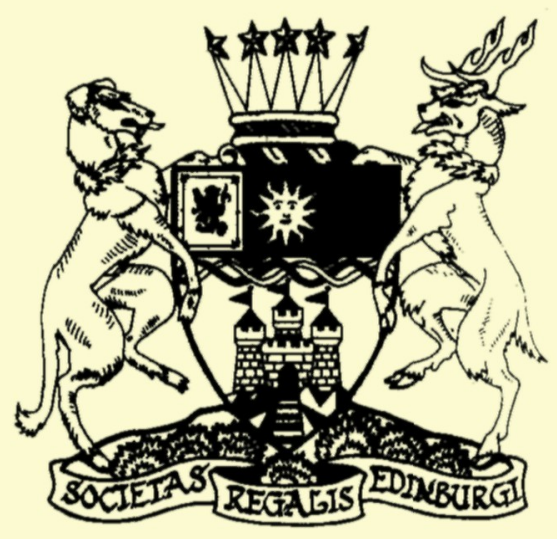

The Royal Society of Edinburgh

Proceedings Section B (Biological Sciences), vol 101

PUBLISHED BY THE ROYAL SOCIETY OF EDINBURGH 22 GEORGE STREET, EDINBURGH EH2 2PQ 


\section{EDITORIAL BOARD}

\section{Executive Editors}

\author{
R. WATLING \\ Royal Botanic Garden Edinburgh
}

\author{
J. A. Allen \\ University Marine Biological Station, \\ Millport
}

I. A. D. BouchIER

The Royal Infirmary Edinburgh

W. C. BOWMAN

University of Strathclyde

R. M. M. Crawford

University of St Andrews

G. W. GOODAY

University of Aberdeen

F. WILLETT

Curator

Glasgow
A. D. MCINTYRe

Aberdeen

W. R. MORRISON

University of Strathclyde

C. J. SUCKLING

University of Strathclyde

M. B. WILKINS

University of Glasgow

Publications Manager, Royal Society of Edinburgh: T. G. DART

\section{Copyright}

(C) 1993 The Royal Society of Edinburgh and the authors of individual papers.

It is the policy of the Royal Society of Edinburgh not to charge any royalty for the production of a single copy of any one article made for private study or research. Specific permission will not be required for photocopying multiple copies of copyright material, to be used for bona fide educational purposes, provided this is done by a member of the staff of the university, school or other comparable institution, for distribution without profit to student members of that institution and provided the copies are made from the original journal. Requests for the copying or reprinting of any article for any other purpose should be sent to the Royal Society of Edinburgh, 22/24 George Street, Edinburgh EH2 2PQ. 


\title{
PROCEEDINGS
}

\author{
OF THE
}

ROYAL SOCIETY OF EDINBURGH 


\section{PROCEEDINGS}

OF

\section{THE ROYAL SOCIETY OF EDINBURGH}

Section B (Biological Sciences)

VOL. 101

1993

\section{PUBLISHED BY \\ THE ROYAL SOCIETY OF EDINBURGH \\ 22 GEORGE STREET \\ EDINBURGH EH2 2PQ}

1993 


\section{QUALITY ASSURANCE IN MEDICAL CARE}

Edited by I. A. D. BOUCHIER, J. S. BECK and I. RUSSELL 


\section{QUALITY ASSURANCE IN MEDICAL CARE}

(Edited by I. A. D. Bouchier, J. S. Beck and I. Russell)

\section{CONTENTS}

Preface

ix

List of authors $\quad$ xi

Quality and standards in health care 1

by D. H. IRVINE and L. DONALDSON

The measurement of process and the role of information technology by M. P. RYAN and W. DoDD

The measurement of patient outcomes

by S. NAJi and T. A. Sheldon

Scientific and methodological issues in quality assurance by I. Russell, J. Grimshaw and B. WiLson

Quality assurance from the perspective of health economics by A. WiLliams

Clinical audit in hospital by D. A. Heath

Quality assurance in general practice by $R$. BAKER and $O$. SAMUEL

Quality assurance in nursing practice by A. KITSON

Quality assurance in the management of chronic disease by J. C. Petrie

Quality assurance in surgical practice by S. J. NIXON

Quality assurance in maternity care by M. H. Hall and R. Currell

by S. L. Jeffcoate, M. J. Corbel, P. D. Minor, R. Gaines-Das and G. C. SCHILD

Drug compliance

by M. R. LEE

Quality assurance in the blood transfusion services

by J. D. CASH 


\section{Contents}

Quality assurance in clinical biochemistry

by C. G. Fraser

Quality assurance in histopathology

by A. J. Robertson and J. S. BeCK

Quality assurance in laboratory haematology

by S. M. LEwIS

Quality assurance in medical microbiology

by J. J. S. SNell and R. Hurley

Quality assurance in radiology

by A. K. Dixon, C. E. L. Freer and D. S. Appleton

Quality assurance in biomedical and health services research by A. T. B. MoIr and I. A. D. Bouchier

Quality assurance in medical publication by S. LOCK 